\title{
Secreted Secondary Metabolites Reduce Bacterial Wilt Severity of Tomato in Bacterial-Fungal Co-Infections
}

\author{
Nandhitha Venkatesh ${ }^{1,2}$, Max J. Koss ${ }^{2}$, Claudio Greco ${ }^{2,+} \oplus$, Grant Nickles ${ }^{2}\left(\right.$ ) , Philipp Wiemann ${ }^{2} \mathbb{C}$ \\ and Nancy P. Keller $2,3, *$ (i) \\ 1 Department of Plant Pathology, University of Wisconsin-Madison, Madison, WI 53706, USA; \\ thiruvannama@wisc.edu \\ 2 Department of Medical Microbiology and Immunology, University of Wisconsin-Madison, \\ Madison, WI 53706, USA; mjkoss@wisc.edu (M.J.K.); claudio.greco@jic.ac.uk (C.G.); \\ gnickles@wisc.edu (G.N.); philipp.wiemann@solugentech.com (P.W.) \\ 3 Department of Bacteriology, University of Wisconsin-Madison, Madison, WI 53706, USA \\ * Correspondence: npkeller@wisc.edu; Tel.: +1-608-262-9795 \\ + Current address: Department of Molecular Microbiology, John Innes Centre, Norwich NR4 7UH, UK.
}

Citation: Venkatesh, N.; Koss, M.J.; Greco, C.; Nickles, G.; Wiemann, P.; Keller, N.P. Secreted Secondary Metabolites Reduce Bacterial Wilt Severity of Tomato in Bacterial-Fungal Co-Infections. Microorganisms 2021, 9, 2123. https://doi.org/10.3390/ microorganisms 9102123

Academic Editors:

Carlos García-Estrada and Carlos Barreiro

Received: 3 September 2021

Accepted: 1 October 2021

Published: 9 October 2021

Publisher's Note: MDPI stays neutral with regard to jurisdictional claims in published maps and institutional affiliations.

Copyright: (c) 2021 by the authors. Licensee MDPI, Basel, Switzerland. This article is an open access article distributed under the terms and conditions of the Creative Commons Attribution (CC BY) license (https:// creativecommons.org/licenses/by/ $4.0 /)$.

\begin{abstract}
In order to gain a comprehensive understanding of plant disease in natural and agricultural ecosystems, it is essential to examine plant disease in multi-pathogen-host systems. Ralstonia solanacearum and Fusarium oxysporum $f$. sp. lycopersici are vascular wilt pathogens that can result in heavy yield losses in susceptible hosts such as tomato. Although both pathogens occupy the xylem, the costs of mixed infections on wilt disease are unknown. Here, we characterize the consequences of co-infection with $R$. solanacearum and F. oxysporum using tomato as the model host. Our results demonstrate that bacterial wilt severity is reduced in co-infections, that bikaverin synthesis by Fusarium contributes to bacterial wilt reduction, and that the arrival time of each microbe at the infection court is important in driving the severity of wilt disease. Further, analysis of the co-infection root secretome identified previously uncharacterized secreted metabolites that reduce $R$. solanacearum growth in vitro and provide protection to tomato seedlings against bacterial wilt disease. Taken together, these results highlight the need to understand the consequences of mixed infections in plant disease.
\end{abstract}

Keywords: secondary metabolites; plant-microbe interactions; coinfection; wilt disease; bacterialfungal interactions; Fusarium oxysporum; Ralstonia solanacearum

\section{Introduction}

The soil microbiome plays a vital role in plant health [1] and microbial communication greatly alters disease outcomes [2]. The co-occurrence and interactions between soil microbes and their hosts fall on a spectrum-from mutualism, competition, or antagonism to simple coexistence-all mediated by direct interactions with each other and/or hostmediated responses [3]. Metagenomic studies have enabled the identification of several co-infection pathosystems where the multi-pathogen-host interactions alter pathogen growth and fitness [4,5] as well as epidemiological outcomes and virulence evolution [6]. Further, mechanistic insights on pathogen communication and changes in host response during co-infection can inform creative and novel disease management strategies. These examples emphasize the need to study the role of microbial interactions in plant diseases within multi-pathogen-host systems.

The challenges of mixed infections in human disease have been increasingly documented in recent years $[7,8]$ and are further highlighted by recent lethal combinations of COVID-19 and other infections [9,10]. However, this topic still remains in its infancy in plant disease. Ralstonia solanacearum and Fusarium oxysporum, bacterial and fungal plant pathogens that cause wilt disease, can lead to yield losses up to $90 \%$ [11] and $80 \%$, respectively, in a wide range of hosts $[12,13]$. While these pathogens have been studied in single 
pathogen-host systems, consequences of mixed infections are unknown. Previous studies from our lab showed that $R$. solanacearum can invade fungal chlamydospores and induce the production of antibacterial mycotoxins by Fusarium spp. [14]. The two pathogens significantly overlap in their presence across the world (based on CABI distribution data $[15,16]$ ) as their optimal growth temperatures are between $28-30{ }^{\circ} \mathrm{C}$ and the microbes display similar infection routes and colonize xylem vessels of the plant. Furthermore, $R$. solanacearum infection has been shown to alter rhizosphere compounds that in turn promote the growth of Fusarium sp. [17]. Given such overlap in conditions for the growth of the two pathogens and host infection and their ability to interact in vitro, we deemed it likely that they can interact in the context of disease development, reminiscent of the reported co-infections of the pulmonary system $[18,19]$.

Using tomato as the common susceptible host, we find that disease severity is significantly modulated by co-infection with the two wilt pathogens. Following previous reports, we find that single infections of $R$. solanacearum result in more rapid wilting and increased severity than single infections of F. oxysporum $f$. sp. lycopersici (hereafter referred to as Fol). In mixed infections, bacterial wilt severity and bacterial burden in the shoot vasculature are significantly reduced compared to $R$. solanacearum single infections. We show that the severity of wilt disease is dependent on the arrival time of the two microbes at the root infection court. In cases of co-infection where both microbes arrive simultaneously or when Fol reaches the root first, $R$. solanacearum wilt severity and $R$. solanacearum recovery from stem tissues are significantly reduced. We further find that bikaverin, an antibacterial metabolite produced by Fol, contributes to the reduction in bacterial success in co-infections. Lastly, we identify several uncharacterized secreted secondary metabolites from co-infected tomato rhizosphere that protect tomato seedlings from $R$. solanacearum wilt.

\section{Results}

\subsection{Bacterial Wilt Severity Is Significantly Reduced in Co-Infections}

To study the consequences of co-infection, we developed a co-infection model to simultaneously inoculate 'Moneymaker' tomato plants with both $R$. solanacearum and Fol (Figure S1). Co-infection resulted in significantly reduced bacterial wilt disease 9 days post infection (dpi) compared to R. solanacearum single infections (Figure 1A,B; two-way repeated measures ANOVA $p<0.0001$; Tukey's Rs vs. Rs+Foxy $p<0.0001)$. Colonization by $R$. solanacearum was also significantly reduced in co-infected stem tissues (Figure 1C; Mann Whitney $\mathrm{U}$ test $p<0.0001$ ) demonstrating that the decrease in disease severity is associated with a reduced number of $R$. solanacearum cells in the shoot xylem. Interestingly, co-infected plants showed all-or-nothing wilt phenotypes, i.e., co-infected plants either completely succumbed to Ralstonia invasion and wilted completely or showed no wilt 9 dpi (Figure 1A,B) and correspondingly much lower colonization by Ralstonia (Figure 1D; ANOVA $p=0.0011$; Tukey's multiple comparisons $p<0.01$ ). In contrast to the impact of co-infection on bacterial invasion, disease symptomology in co-infected plants over $48 \mathrm{dpi}$ mirrored that of single infections with Fol (Figure 1E; ANOVA $p=0.0001$; Tukey's Foxy vs. Rs+Foxy $p=0.9993$ ) with no differences in fungal colonization between co-infections and Fol single infections (Figure 1F; Mann-Whitney $U$ test $p=0.3610$ ). Co-culture of $R$. solanacearum and Fol in vitro do not show loss of bacterial viability $24 \mathrm{~h}$ post inoculation (Figure S2). This indicates that the reduction in Ralstonia solanacearum colonization during host co-infection is not due to loss of bacterial viability in the coinfection inoculum. Together, the data show that bacterial wilt severity is reduced in co-infections. 
(A)

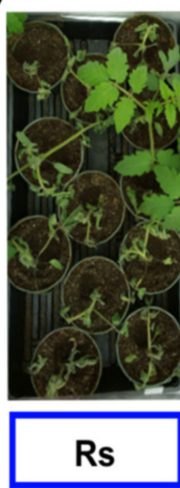

9 dpi

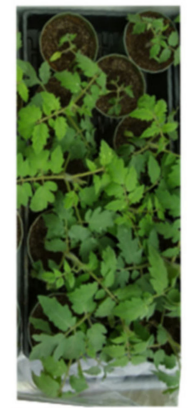

Rs + Foxy

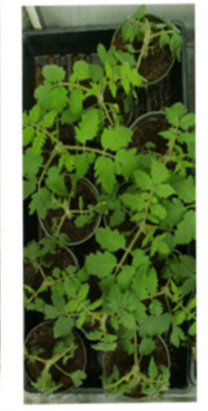

Foxy

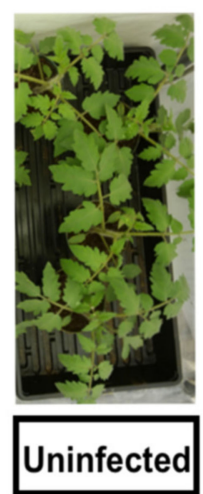

(B)

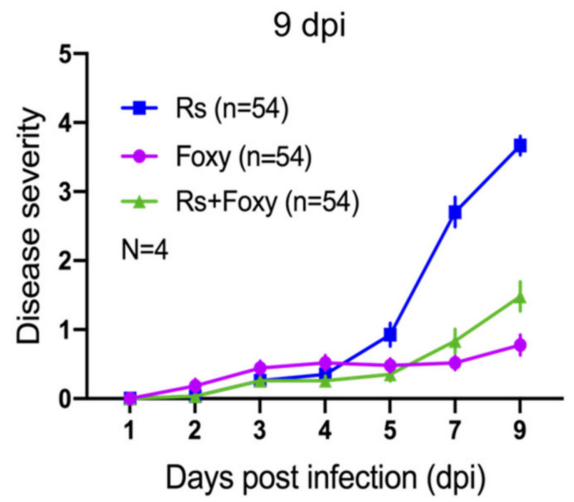

(C)

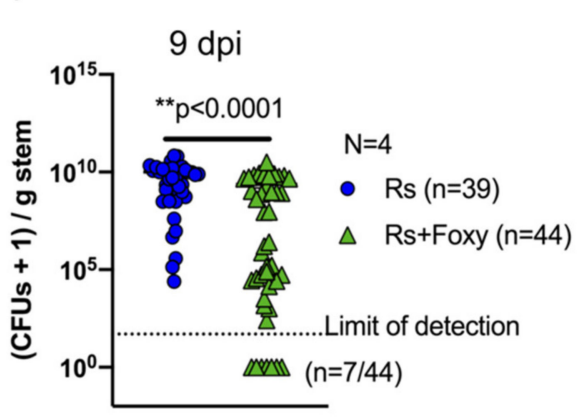

(E)

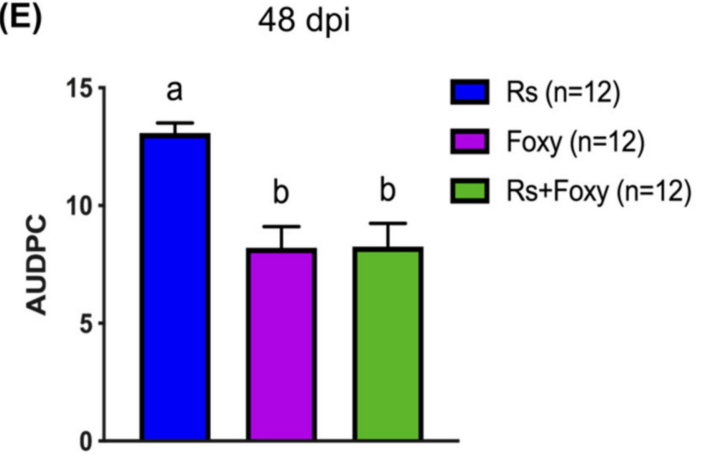

(D) Rs colonization

$9 \mathrm{dpi}$

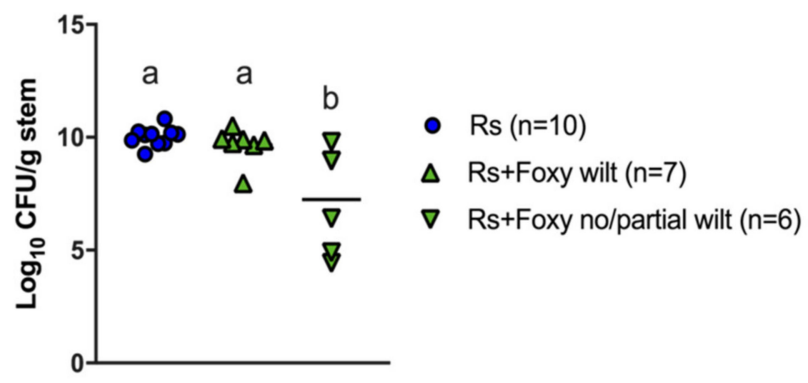

(F)

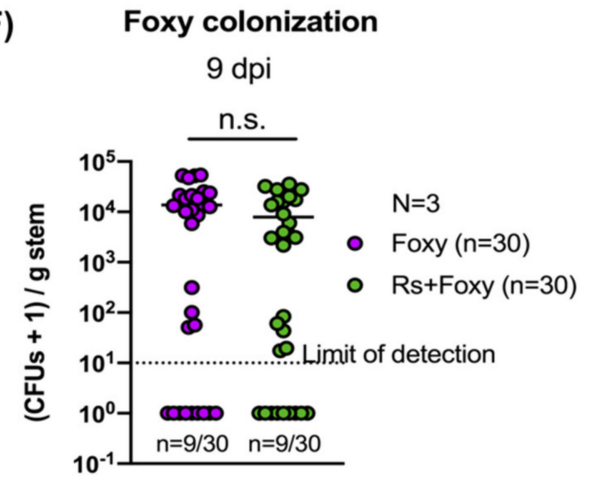

Figure 1. Co-infection reduces bacterial wilt severity. (A) Single-infected and co-infected showing differential wilting symptoms 9 days post infection (dpi). R. solanacearum = Rs; F. oxysporum (Foxy). (B) Wilt symptoms were scored every day for $9 \mathrm{dpi}$ and quantified. Two-way repeated-measures ANOVA was performed with time $\mathrm{x}$ treatment $p=0.0001$. Tukey's multiple comparisons showed significantly different disease between Rs vs. Foxy $(p<0.0001)$ and Rs vs. Rs+Foxy $(p<0.0001)$. No significant difference in symptoms was observed between Foxy and Rs+Foxy $(p=0.7867)$. (C) Bacterial colony forming units (CFUs) quantified $9 \mathrm{dpi}$ from shoots $1 \mathrm{~cm}$ above the cotyledons showed reduced bacterial burden in co-infection compared to single $R$. solanacearum infections. All CFU data in this work is presented as CFUs +1 to take into account samples below the detection limit, denoted under each dataset. Mann-Whitney's U test was performed with $p<0.0001$. (D) Co-infected plants that fully wilted had bacterial burden equal to plants infected with only $R$. solanacearum (ANOVA $p=0.0011$; Tukey's $p=0.8259$ ). Co-infected plants that showed no/partial wilt symptoms had bacterial burden lower than R. solanacearum single infections (Tukey's $p=0.0011$ ). (E) Disease was quantified over 48 days based on disease incidence. ANOVA was performed on AUDPC with $p=0.0001$. No significant difference in overall disease was observed between co-infection and F. oxysporum single infections (Tukey's $p=0.9993$ ). (F) F. oxysporum CFUs quantified from shoot tissues 9 dpi show no significant differences in fungal burden. Mann-Whitney's U test $p=0.3610$. 


\subsection{Co-Infection Disease Phenotype Requires Specific Interactions with Live F. oxysporum $f$. sp. lycopersici}

To gain insight into how Fol contributed to a reduction in bacterial wilt disease during co-infection, we first asked if the live fungus was needed. When $R$. solanacearum was co-inoculated with dead Fol conidia (heat killed by exposure to $60{ }^{\circ} \mathrm{C}$ for $6 \mathrm{~h}$, verified by plating), bacterial wilt was more severe than in $R$. solanacearum single infections (Figure S3) (two-way repeated measures ANOVA $p=0.0005$; Tukey's test Rs vs. Rs + dead Foxy $p=0.0227)$.

We then asked if the interactions were specific to F. oxysporum f. sp. lycoperisici that can invade tomato xylem. To test this hypothesis, we co-infected tomato plants with $F$. oxysporum $f$. sp. tulipae (Fot), a strain non-pathogenic to tomatoes but pathogenic to tulips. Co-infection of $R$. solanacearum with F. oxysporum $f$. sp. tulipae did not reduce bacterial wilt severity (Figure S3) (two-way repeated measures ANOVA $p=0.0005$; Tukey's test Rs vs. Rs + Fot $p=0.2136$ ). Together, the results suggest that interactions specific to F. oxysporum $f$. sp. lycopersici are required for the reduction in bacterial wilt severity.

\subsection{Early Interactions Play Vital Roles in Co-Infection Disease Outcome}

To understand the mechanisms underlying the reduction in bacterial wilt in coinfections, we tested if the arrival time of the pathogens impacted disease severity during co-infection. Figure 2A and Figure S4 show the infection timelines for $R$. solanacearum and Fol single infections, respectively, assembled from previously published works (references for $R$. solanacearum [20-25] and Fol [26,27] are indicated in the figures). R. solanacearum infection at the root begins with recognition of and irreversible attachment to root hairs, secondary and lateral root emergent sites. This is followed by intercellular invasion into the root cortex past the epidermis, intracellular colonization of cortical cells, finally leading up to systemic invasion and colonization of the plant vascular system resulting in wilting symptoms. Adhesion of $R$. solanacearum cells to the root was not significantly different in simultaneous co-infection compared to $R$. solanacearum single infection (Figure S5).

In order to delineate the relevant time points, $R$. solanacearum was given a headstart of $1 \mathrm{~h}, 5 \mathrm{~h}$, and $24 \mathrm{~h}$. Even after a $1 \mathrm{~h}$ headstart, bacterial wilt severity was rescued in co-infections (Figure 2B; two-way repeated-measures ANOVA $p<0.0001$; 1 h headstartRs+Foxy vs. Rs $p=0.6131 ; 1$ h-headstart-Rs+Foxy vs. Rs+Foxy $p=0.0001$ ). Head starts of $5 \mathrm{~h}$ and $24 \mathrm{~h}$ also resulted in co-infection wilt severity comparable to $R$. solanacearum single infections (data not shown). With a 1 h headstart, bacterial CFUs recovered from coinfections were similar to numbers recovered from $R$. solanacearum single infections (Figure 2C; ANOVA $p<0.0001$; Tukey's 1h-headstart-Rs+Foxy vs. Rs $p=0.7123$ ). On the other hand, a 1 h headstart to Fol resulted in significantly lower disease compared to simultaneous co-infection (Figure 2D; two-way repeated-measures ANOVA $p<0.0001$; Tukey's Rs+Foxy vs. 1 h-headstart-Foxy+Rs $p=0.0006)$ and reduced bacterial burden (Figure 2C; Tukey's Rs+Foxy vs. 1 h-headstart-Foxy+Rs $p<0.000$ ). A 1 h headstart to Fol in co-infections also resulted in lower disease compared to Fol single infections (Figure 2D; two-way repeated-measures ANOVA $p<0.0001$; Tukey's Foxy vs. 1 h-headstart-Foxy+Rs $p=0.0095)$. These results strongly suggest that early bacterial-fungal interactions determine the bacterial fate in planta and the consequent infection outcome.

\subsection{A Role for Bikaverin in Bacterial Wilt Suppression}

Previous work from our lab has shown that the lipopeptide ralsolamycin produced by $R$. solanacearum induced the synthesis of bikaverin in Fusarium spp. including Fol in in vitro co-cultures [28]. Bikaverin, a polyketide secondary metabolite showed potent antibiotic activity against $R$. solanacearum activity in vitro [28]. Further, our results show that co-infections of $R$. solanacearum with Fot do not alter bacterial wilt severity. Interestingly, a protein BLAST analysis with the bikaverin polyketide synthase from F. fujikuroi (XP_023430071.1) as query returned no significant similarity matches in the Fot genome. Based on these results, we hypothesized that bikaverin production could play a role in 
the reduction of bacterial wilt disease during co-infections. To address this hypothesis, bik1 (encoding the polyketide synthase required for bikaverin synthesis) was deleted in F. oxysporum f. sp. lycopersici (Figure S6A-C). Co-infection of R. solanacearum with $\Delta b i k 1$ Fol unable to produce bikaverin (Figure S6D) resulted in a partial rescue of bacterial wilt (Figure 3A) (two-way ANOVA time $\mathrm{x}$ treatment $p<0.0001$; Tukey's test: Rs + WT Foxy vs. Rs $+\Delta b i k 1$ Foxy $p=0.0002$; WT Foxy vs. $\Delta b i k 1$ Foxy $p=0.9994$ ) and bacterial burden (Figure 3B) (Mann-Whitney U test $p=0.0472$ ), indicating the contribution of bikaverin to a reduction in bacterial wilt and colonization in co-infection.

(A)

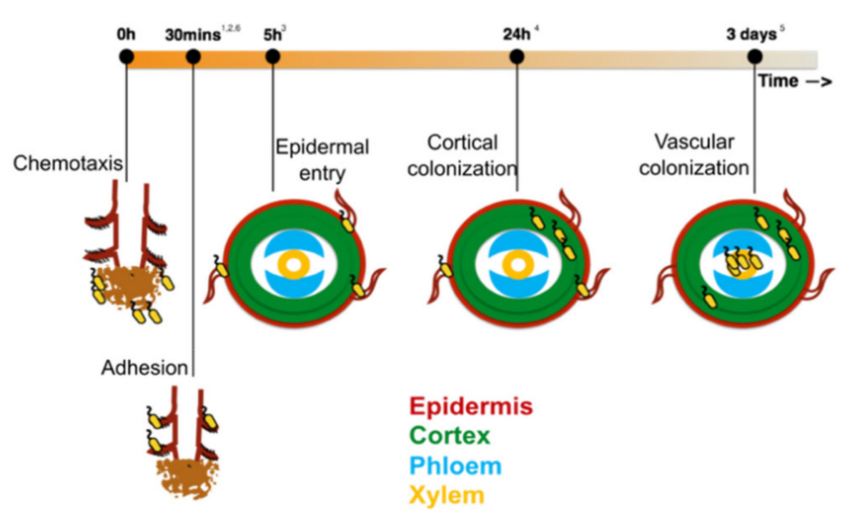

(B)

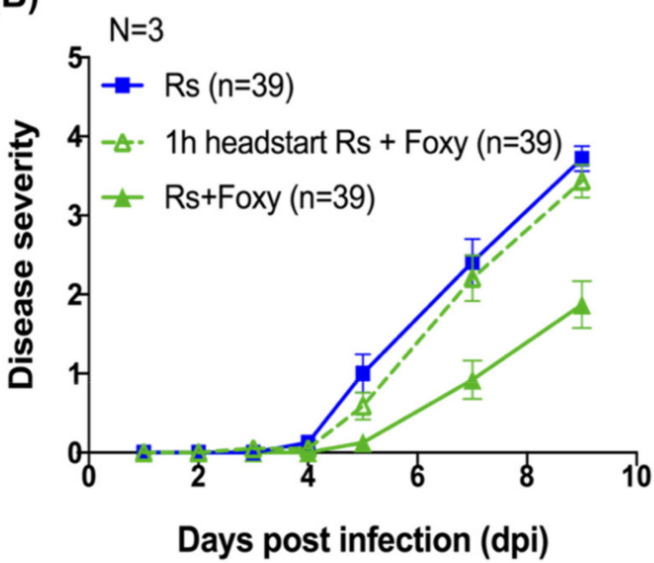

'Yao et al. J. Bacteriol. $2006{ }^{2}$ Hoffman et al. Anal. Chem. 2015 3McGarvey et al. Bacteriology $1999{ }^{4}$ Caldwell et al. Phytopathology 2017 sVasse et al. Mol. Plant Microbe Interact. 1995 'Lowe-Power et al. Trends Microbiol. 2017
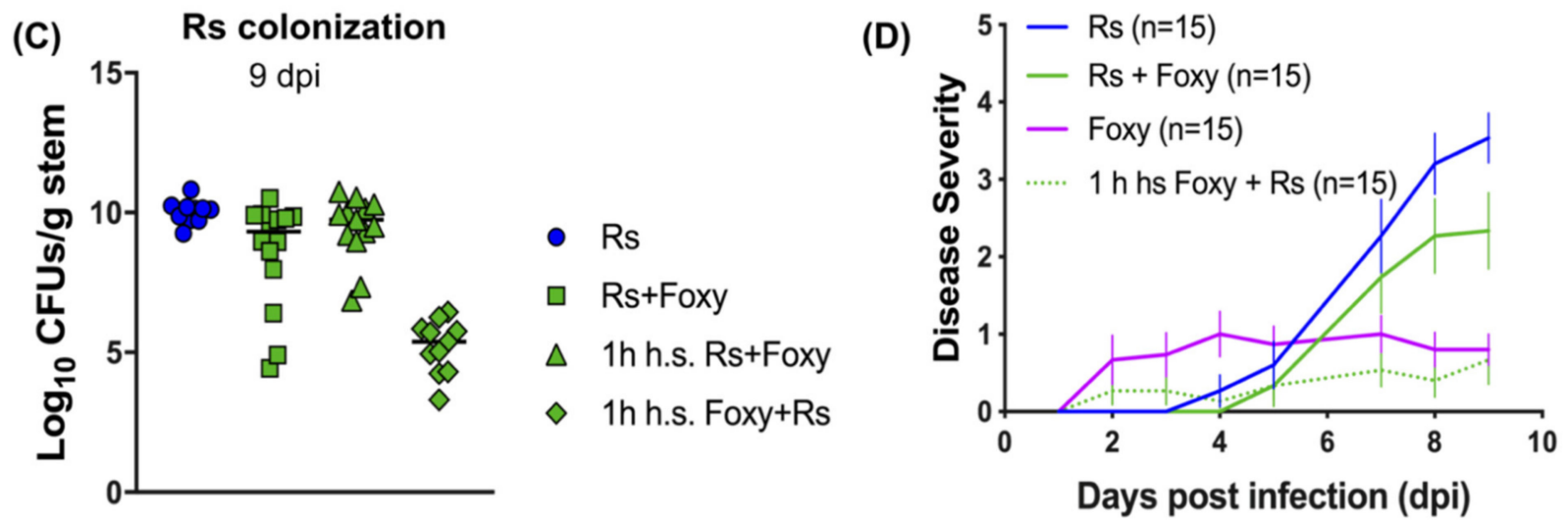

Figure 2. Early interactions determine co-infection outcome. (A) timeline for $R$. solanacearum infection from recognition of the host until colonization of the xylem, gathered from available literature. (B) The figure shows disease severity over 9 days for $1 \mathrm{~h}$ head-start to $R$. solanacearum in co-infection ( $1 \mathrm{~h}$ headstart Rs + Foxy) with relevant controls. Two-way repeated-measures ANOVA was performed with time $\mathrm{x}$ treatment $p<0.0001$. A $1 \mathrm{~h}$ head-start to $R$. solanacearum in co-infection resulted in disease equal to $R$. solanacearum single infection ( $1 \mathrm{~h}$ headstart Rs+Foxy vs. Rs-Tukey's $p=0.6131$ ). Simultaneous co-infection resulted in reduced disease (Rs+Foxy vs. $1 \mathrm{~h}$ headstart Rs+Foxy-Tukey's $p=0.0001$ ). (C) CFUs of $R$. solanacearum from shoot tissue $9 \mathrm{dpi}$; ANOVA $p<0.0001$. While co-infection resulted in reduced colonization (Rs vs. Rs+Foxy Tukey's $p=0.0452)$, a $1 \mathrm{~h}$ head-start to $R$. solanacearum resulted in similar colonization as found in bacterial single infections (Rs vs. $1 \mathrm{~h}$ h.s. Rs+Foxy Tukey's $p=0.7123$ ). (D) shows disease severity over 9 days for $1 \mathrm{~h}$ head-start to $F$. oxysporum in co-infection ( $1 \mathrm{~h}$ h.s. Foxy $+\mathrm{Rs}$ ) with relevant controls. Two-way repeated-measures ANOVA was performed with time $\mathrm{x}$ treatment $p<0.0001$. A $1 \mathrm{~h}$ headstart to F. oxysporum in co-infection resulted in lower disease than simultaneous co-infection (Rs+Foxy vs. 1 h h.s. Foxy+Rs-Tukey's $p=0.0006)$. 


\subsection{Secondary Metabolites in Early Co-Infection Secretome Reduce Bacterial Growth In Vitro}

As bikaverin synthesis only partially contributed to the co-infection bacterial wilt suppression and the arrival time of each microbe significantly altered disease during coinfection, we hypothesized that additional early interactions in the rhizosphere played a significant role in the co-infection outcome. As a way of capturing the root co-infection environment, we collected the total rhizosphere secretome from the tri-trophic interaction. The total secretome would contain plant root exudates, as well as secondary metabolites, proteins, lipids and sugars secreted by both microbes and the plant. Studies of plant response in single-pathogen-host systems have identified changes in the composition of root exudates in response to R. solanacearum [28], Fol [29] as well as other pathogens [30].

(A)

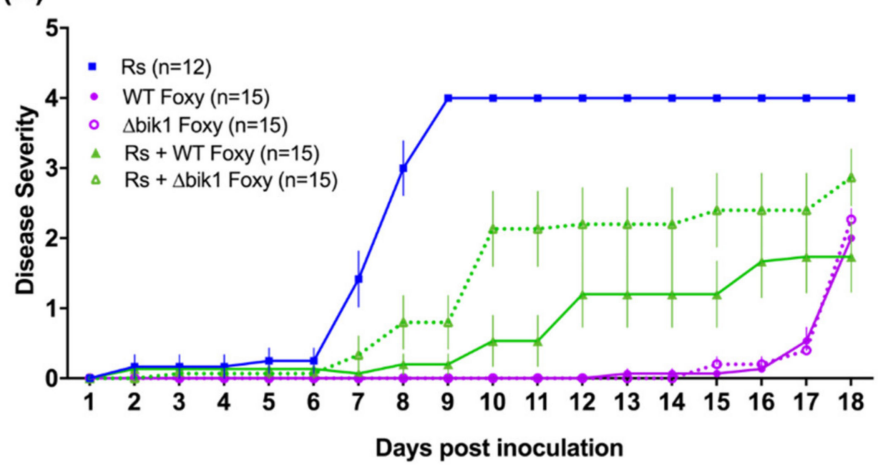

(B) Rs colonization

$9 \mathrm{dpi}$

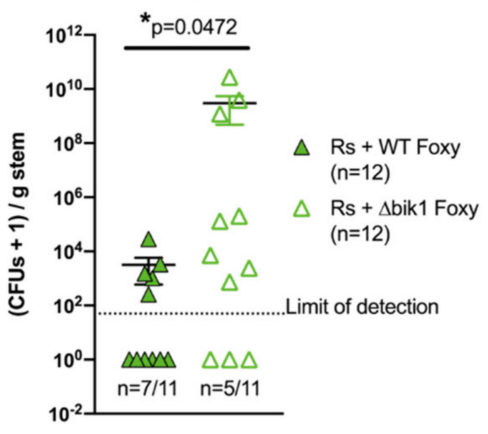

Figure 3. Bikaverin contributes to the reduction in bacterial wilt in co-infections. (A) Disease severity scores were assigned daily for 18 days. ' $\triangle$ bik1 Foxy' refers to the $F$. oxysporum strain whose backbone polyketide synthase gene (bik1) required for bikaverin production was deleted. Two-way repeatedmeasures ANOVA was performed with time $\mathrm{x}$ treatment $p=0.0001$. Tukey's multiple comparisons showed significantly different disease between Rs + WT Foxy and Rs + $\Delta b i k 1$ Foxy $(p=0.0002)$, Rs vs. Rs + WT Foxy $(p<0.0001)$, and Rs vs. Rs $+\Delta b i k 1$ Foxy $(p<0.0001)$. No significant difference in symptoms was observed between WT Foxy and $\Delta b i k 1$ Foxy $(p=0.9994)$. (B) Bacterial CFUs recovered 9 dpi from shoots $1 \mathrm{~cm}$ above the cotyledons from plants co-infected with $R$. solanacearum and WT or $\triangle b i k 1$ F. oxysporum strains. CFUs are presented as CFUs +1 to take into account samples below detection limit, denoted nder each dataset. The data was non-normal. Mann-Whitney's U test was performed with $p=0.0472$. 
Total growth of $R$. solanacearum in the secretomes collected from each treatment $(R$. solanacearum single infection, F. oxysporum single infection, $R$. solanacearum-F. oxysporum co-infection, and uninfected control) was measured as the area under the growth curves (AUC) over $48 \mathrm{~h}$. Comparison of AUCs showed a significant reduction in growth of $R$. solanacearum in the co-infection secretome compared to secretomes from single infections (Figure 4A; ANOVA $p=0.0003$; Tukey's Rs vs. Rs+Foxy $p=0.0048$; Tukey's Foxy vs. Rs+Foxy $p=0.0002)$. R. solanacearum did not show reduced viability upon co-culture in vitro in the buffer used to collect total secretome (Figure S7). We tested bacterial growth in co-infection secretomes that were heat inactivated $\left(100{ }^{\circ} \mathrm{C}\right.$ for $5 \mathrm{~min} ; 60{ }^{\circ} \mathrm{C}$ for $\left.1 \mathrm{~h}\right)$ where bacterial growth reduction was maintained (Figure S8). These results suggested that the active molecule(s) in the secretome were not proteins but may be primary or secondary metabolites.

To further characterize the potential bioactive molecules, we performed organic solvent extractions from the secretome, eluting lipids into hexane, sugars, carbohydrates, and some secondary metabolites into a methanol/water mixture and the majority of secondary metabolites into ethyl acetate phases based on their polarities. The total co-infection crude extract from the hexane phase did not show activity against $R$. solanacearum (Figure S9A) whereas the methanol (Figure S9B) and ethyl acetate phases (Figure 4B; ANOVA $p<0.0001$; Tukey's Rs vs. Rs+Foxy $p=0.0005$ ) showed a significant reduction in bacterial growth. Crude ethyl acetate extract Fol single infections also showed a reduction in bacterial growth (Figure 4B; Tukey's Foxy vs. Rs $p=0.0025$ ). We focused our efforts on the ethyl acetate phase to identify small molecules involved in the co-infection disease outcome. We only explored the co-infection crude extract since only the co-infection secretome reduced bacterial growth in vitro. Untargeted metabolomics performed on the ethyl acetate crude extracts showed that the secretome of co-infections and single infections are different from each other (Figure S10A). Twenty-one ions were exclusively enriched only in the co-infection secretome compared to $R$. solanacearum or F. oxysporum single infections or the uninfected control, while five ions were exclusively diminished (Figure S10B). Several of the ions enriched in co-infection returned no annotation matches using the mzCloud and Chemspider databases (Figure S10C,D) suggestive of novel metabolites that may be upregulated in co-infections.

To specifically identify which secondary metabolites contribute most to the reduction in bacterial growth, we collected 20 fractions of the co-infection crude extract from the ethyl acetate phase and tested for activity against $R$. solanacearum growth in vitro. Five fractions were further chosen for chemical analyses as they showed the highest bacterial growth reduction and were purified in enough quantities for downstream analyses (Figure 4C; ANOVA $p<0.0001$; Bonferroni correction for multiple comparisons $p<0.05$ ). Chromatograms of these five fractions are shown in Figure 4D. LC-MS/MS analyses identified ions with no significant matches in any database (Table S1). All fractions when applied to tomato roots immediately after infection with $R$. solanacearum provided protection against bacterial wilt (Figure 5A,B; Brown-Forsythe and Welch ANOVA $p<0.001$; Dunnett's multiple comparisons $p<0.02$ ). 
(A) Rs growth in total secretome

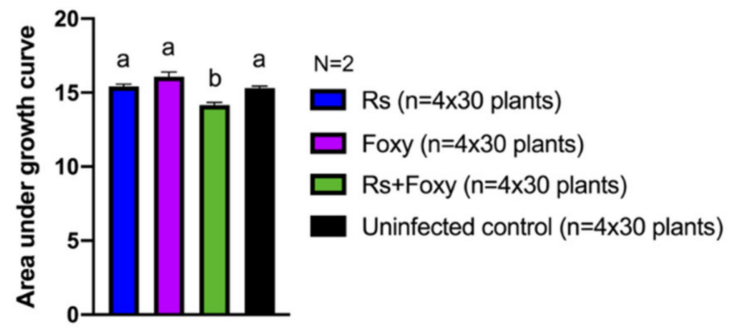

(B) Rs growth in secondary metabolite crude extracts

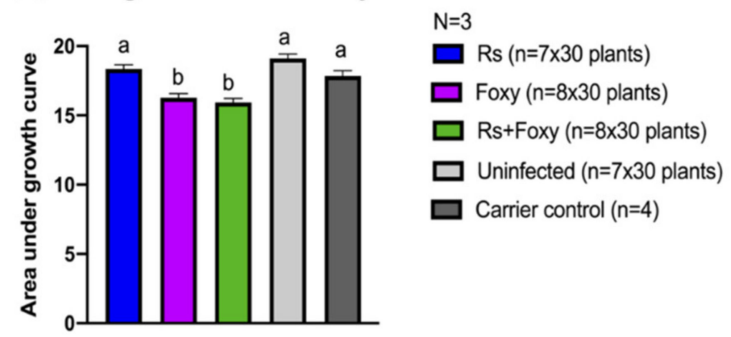

(C) Rs growth in co-infection fractions

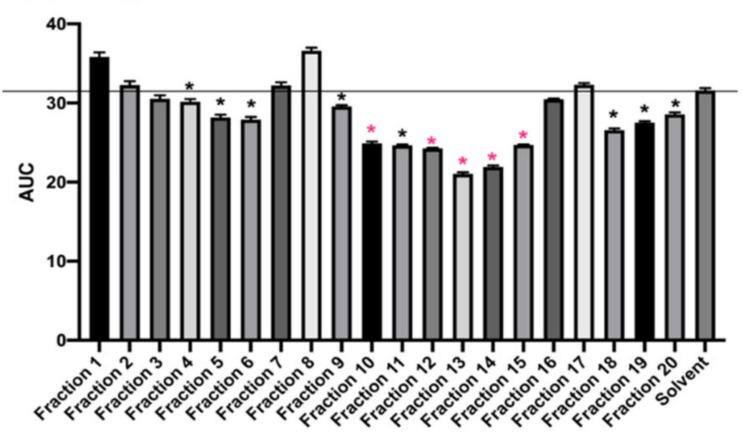

(D)

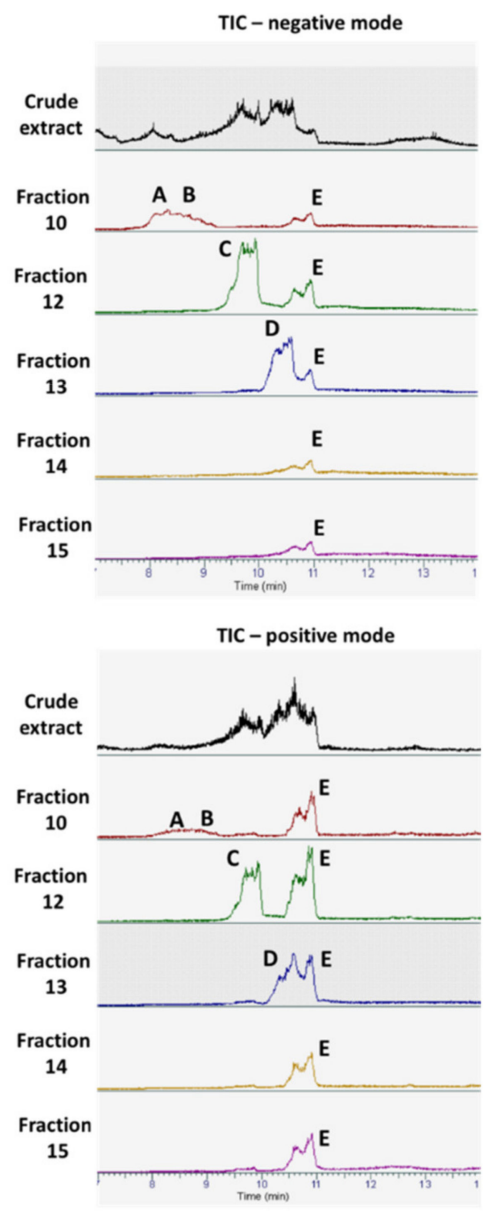

Figure 4. Crude extracts from the co-infection secretome reduce in vitro R. solanacearum growth. (A) shows area under growth curve (AUC) for $42 \mathrm{~h}$ post inoculation (hpi). R. solanacearum was inoculated in total secretome (including plant and microbial secretions) from different treatments as indicated. Bacterial growth in co-infection secretome was significantly reduced compared to secretomes from single infections (ANOVA $p=0.0003$; Rs vs. Rs+Foxy-Tukey's $p=0.0049$; Foxy vs. Rs+Foxy-Tukey's $p=0.0001)$. (B) shows R. solanacearum growth as AUC up to 48 hpi in crude extracts eluted into ethyl acetate. ANOVA $p<0.0001$. Rs vs. Rs+Foxy-Tukey's $p=0.0005$; Foxy vs. Rs+Foxy-Tukey's $p=0.9260$. (C) Co-infection crude extract was fractionated and $R$. solanacearum growth was quantified in each fraction. ANOVA $p<0.0001$. Bonferroni correction was performed to compared AUCs between each fraction with the solvent control ${ }^{*} p<0.05$. The fractions marked in pink * $(p<0.0001)$ were chosen for further analyses in (D) and Figure 4. (D) Total ion chromatograms (TIC) of the fractions in positive and negative modes run on HR-ESI-MS. The $\mathrm{m} / \mathrm{z}$ of these peaks (A-E) are reported in Table S1. 
(A) Uninfected

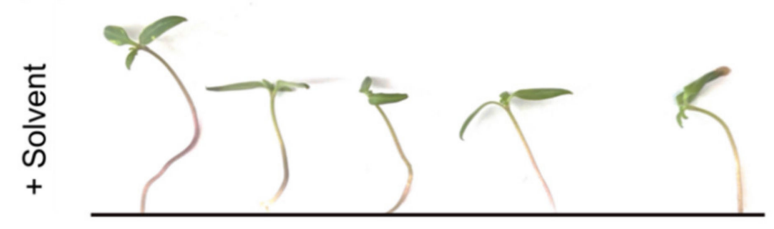

R. solanacearum infected

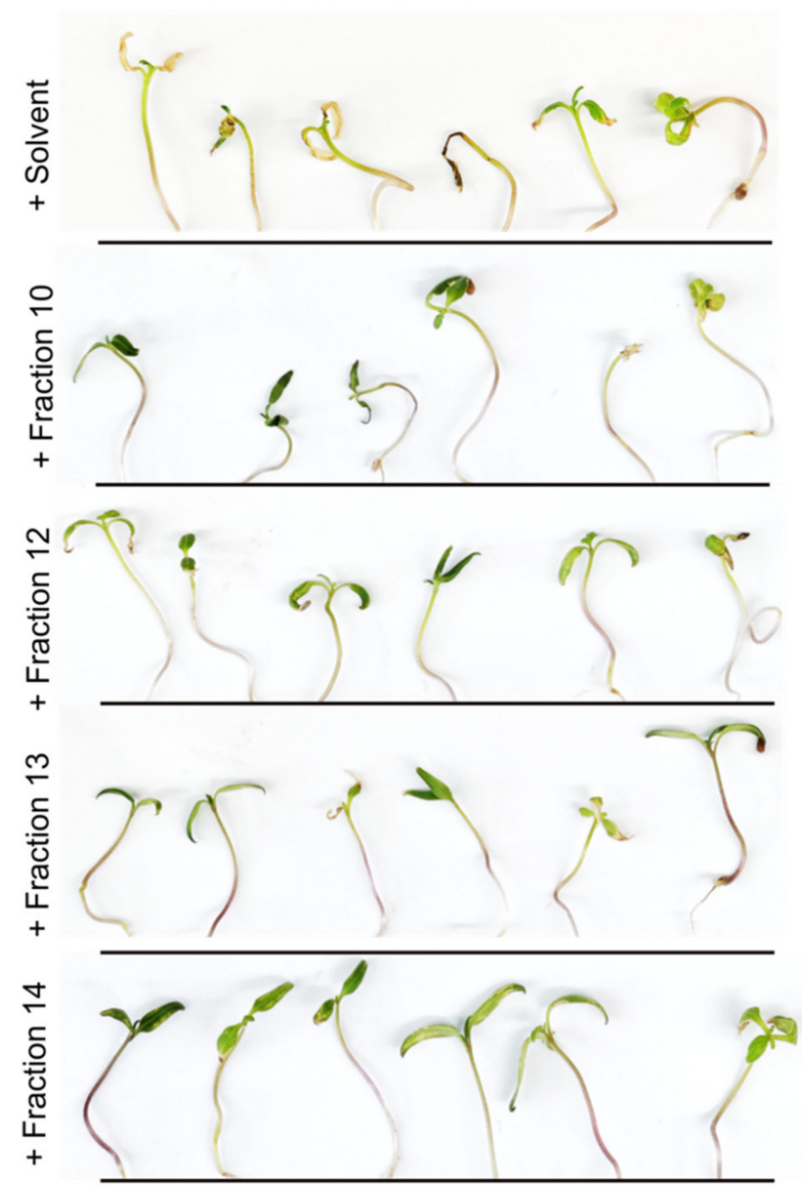

(B)

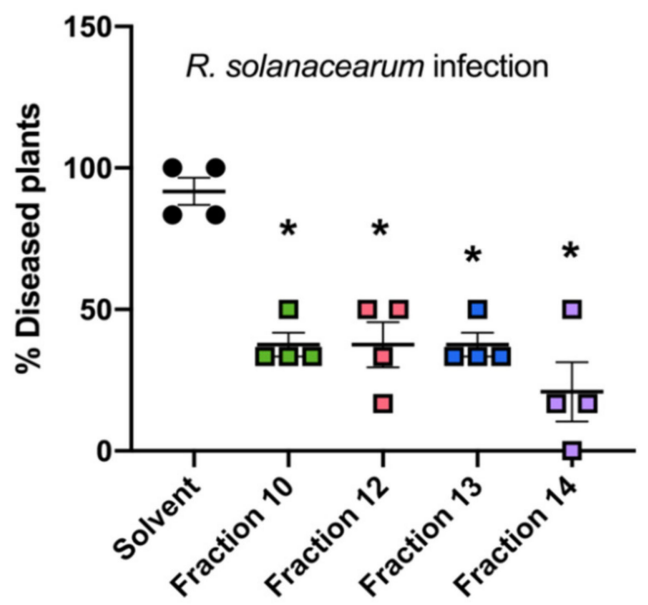

Figure 5. Secondary metabolites from co-infection secretome protect tomato seedlings from $R$. solanaceaum wilt. (A) 11-day old seedlings were infected with $R$. solanacearum after which either $80 \%$ acetonitrile (solvent control) or fractions of the ethyl acetate crude extract were applied to the roots at a final concentration of $1 \%$ by volume in water. The top panel shows an uninfected control for reference. The plants were photographed 6 dpi. (B) Four individuals scored each plant as to whether they were infected or not. The $\%$ diseased plants reported by each person is shown in the graph. ANOVA $p<0.0001$. Bonferroni correction was performed to compare disease between solvent and fractions. In all cases, ${ }^{*} p<0.0003$.

\section{Discussion}

Bacteria and fungi co-occur in large numbers in soil. It is estimated that a gram of soil contains up to 1 billion bacteria and 1 million fungi [31]. Bacteria and fungi are often co-isolated from in-field samples [32] and physically associate with one another in the soil environment [33,34]. Despite the close association of these two Kingdoms in the rhizosphere, surprisingly few efforts have been made to understand the consequences of mixed infections in plant disease. This is in contrast to the increasing number of studies addressing mixed bacterial-fungal infections of humans [2,35]. Our previous studies have identified endofungal behavior of $R$. solanaceaum in fungal species including $F o l$ in in vitro co-cultures where the fungus over-produces bikaverin in response to bacterial invasion $[14,36]$. In soil microcosms, $R$. solanacearum derives overwintering advantages 
in association with Fol. Further, the two pathogens overlap in the range of hosts they infect, share infection routes (via roots to the plant xylem) and cause very similar wilting symptoms in infected plants. Given the remarkable similarities in their infections and their ability to interact in vitro, we considered it prudent to examine the consequences of coinfections by these pathogens. We find that upon co-infection of tomato plants, depending on the temporal dynamics of pathogen arrival at the roots, bacterial wilt severity and bacterial load in the shoot xylem are reduced. We show that bacterial wilt suppression is associated with secondary metabolites, both known (bikaverin) and unknown. The uncharacterized natural products show some promise as biopesticides as they protect tomato plants against $R$. solanacearum wilt.

Our results clearly demonstrate that co-infection reduces bacterial wilt severity (Figure 1). Further, early interactions (up to $\sim 24 \mathrm{~h}$ ) between $R$. solanacearum, Fol and the susceptible tomato host are strong determinants of the infection outcomes (Figure 2). This emphasizes the need for studying early infection events and early intervention efforts for effective management of wilt disease. We also find that the live fungus is required for reduction in bacterial wilt during co-infection (Figure S3) and that Fusarium host specificity may be important (Figure S3). Whether the difference lies in the ability of the fungus to simply invade the roots, cause wilting symptoms, or induce certain plant defense responses could possibly be delineated by examining coinfections with other fungal wilt pathogens such as Verticillium spp. [37] or different strains of Fusarium oxysporum such as the tomato endophyte F. oxysporum Fo47 [38]. Our study also identifies a role for the antibacterial secondary metabolite bikaverin in bacterial disease suppression (Figure 3) and supports our previous results showing inhibition of $R$. solanacearum growth by this metabolite [28]. However, bikaverin presence could not fully account for disease suppression leading us to analyze the infection secretome.

Investigation into the early cross-kingdom secretome at the root identified putative secondary metabolites secreted during co-infection that restricted $R$. solanacearum growth in vitro (Figure $4 \mathrm{~A}, \mathrm{~B}$ ). Fractionation of crude extracts from the co-infection secretome identified several fractions that reduced $R$. solanacearum growth in vitro with novel ions identified with LC-MS/MS analyses (Figure 4C,D; Table S1). In planta evaluation of five of these fractions showed protection to a susceptible tomato host from $R$. solanacearum disease (Figure 5). Bikaverin was not found in the rhizosphere secretome likely due to the early time point at which the metabolome was assessed. It is also possible that bikaverin is more important in later stages of the infection process.

The chemical structures of the secretome metabolites, the producing organism synthesizing these natural products, and their antibacterial mechanisms remain unknown. Future work characterizing the putative novel compounds identified here can evaluate their efficacy in controlling $R$. solanacearum wilt. Current strategies for managing bacterial wilt emphasize prevention as once $R$. solanacearum invades a field the bacterium survives for long periods of time, sometimes up to four years [39]. The primary focus is on the use of resistant cultivars, clean planting and harvest equipment, and quick removal of infected plants from the field as currently available chemical and biological control is often ineffective against $R$. solanacearum [40]. Therefore, new and robust management strategies are a constant need to manage disease. Our results demonstrate that exploring interactions between microbes that share infection niches and routes may be powerful ways of identifying novel bioactive small molecules for disease management. This is an expansion of the already realized power of eliciting the production of bioactive secondary metabolites from in vitro bacterial-fungal co-cultures [41].

A comprehensive model of interaction between R. solanacearum and Fol in soil and in the presence of a susceptible host emerges from our results (Figure 6). This work characterizes co-infection outcomes by two devastating plant pathogens and identifies secondary metabolites at the interface of the cross-kingdom communication, unveiling potentially new biopesticides against $R$. solanacearum wilt. 


\section{Bacterial-fungal interactions alter wilt disease}

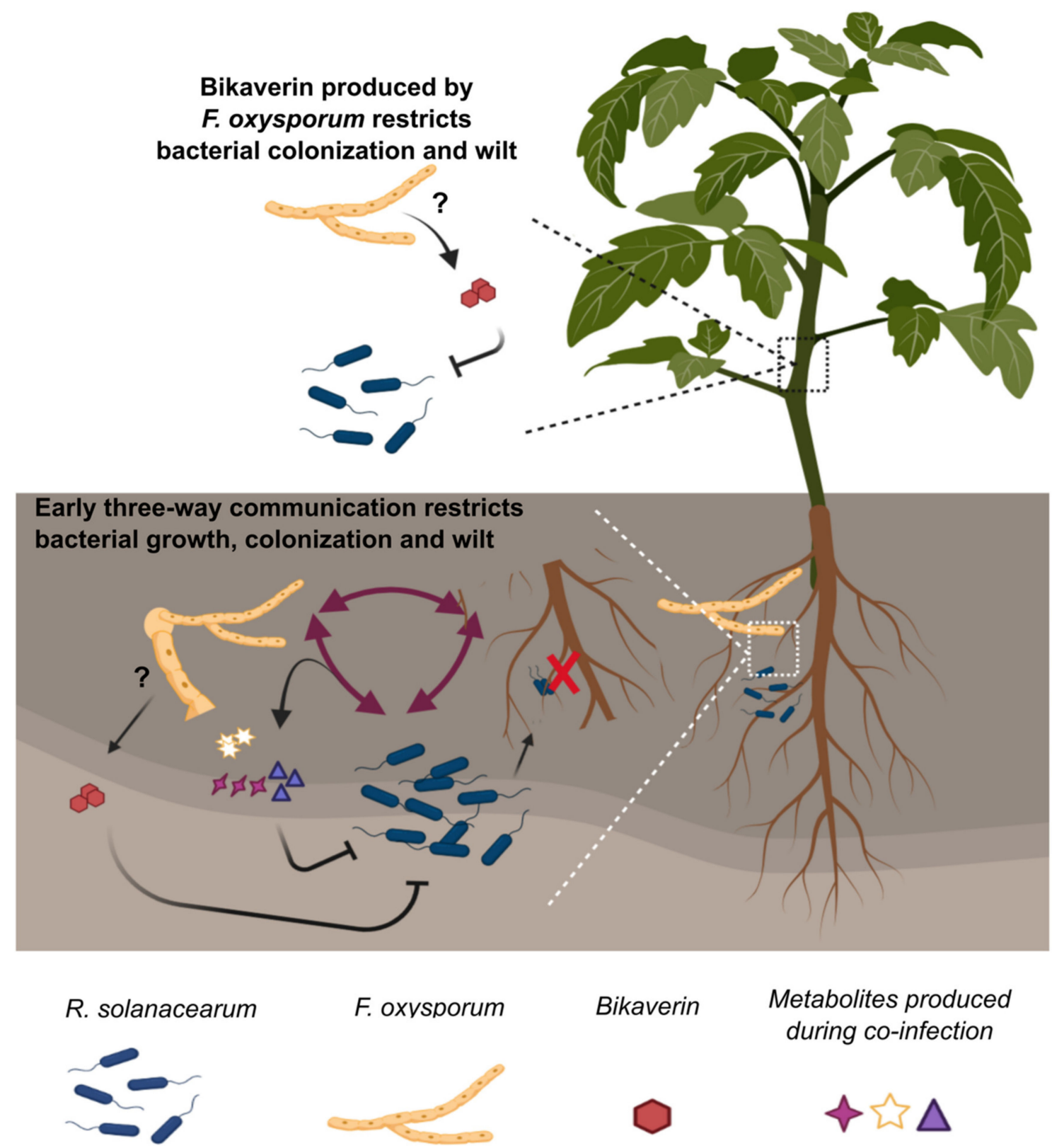

Figure 6. Model for tri-trophic interactions mediating wilt disease. Early interactions between the microbes and the host at the root result in the production of secondary metabolites that inhibit $R$. solanacearum growth and colonization. In the presence of the bacterium, F. oxysporum produces bikaverin, whose antibacterial activity also contributes to reduced colonization by $R$. solanacearum. Whether bikaverin is produced in the rhizosphere or in later stages inside the plant remains to be answered (represented with a question mark). This figure was created with Biorender.com.

\section{Materials and Methods}

\subsection{Microbial Culture Maintenance and Growth Conditions}

All fungal and bacterial strains used in the study and their sources are listed in Table S2. All strains were stored at $-80{ }^{\circ} \mathrm{C}$ in $33 \%$ glycerol. $R$. solanacearum was routinely grown in CPG medium, amended with $0.005 \%$ Tetrazolium chloride, and incubated at $30{ }^{\circ} \mathrm{C}$ for 2 days. Colonies from freshly grown plates were cultivated overnight in liquid $\mathrm{CPG}$ broth at $30^{\circ} \mathrm{C}$ with constant shaking at $250 \mathrm{rpm}$. F. oxysporum f. sp. lycopersici and 
F. oyxposrum $f$. sp. tulipae were routinely grown on PDA for 5 days. Plugs were then transferred to $50 \mathrm{~mL}$ of PDB in $125 \mathrm{~mL}$ flasks and incubated at $30^{\circ} \mathrm{C}$ for 5 days with constant shaking at $250 \mathrm{rpm}$ to raise conidia. For secondary metabolite extractions from fungal cultures, fungal plugs from PDA plates were grown in $50 \mathrm{~mL}$ of liquid ICI media in $125 \mathrm{~mL}$ flasks and incubated at $30^{\circ} \mathrm{C}$ for 5 days with constant shaking at $250 \mathrm{rpm}$.

\subsection{Media Recipes}

CPG (1L): 1 g Casamino acids, 1 g Bacto $^{\mathrm{TM}}$ Yeast Extract, $10 \mathrm{~g}$ Dextrose, $10 \mathrm{~g}$ Bacto $^{\mathrm{TM}}$ Peptone, $16 \mathrm{~g}$ agar.

Boucher's Minimal Medium (BMM $1 \mathrm{~L}): 3.4 \mathrm{~g} \mathrm{KH}_{2} \mathrm{PO}_{4}, 0.5 \mathrm{~g}\left(\mathrm{NH}_{4}\right)_{2} \mathrm{SO}_{4}, 100 \mu \mathrm{L}$ of $1.25 \mathrm{mg} / \mathrm{mL}$ stock solution $\mathrm{FeSO}_{4} 7 \mathrm{H}_{2} \mathrm{O}, 517 \mu \mathrm{L}$ of $1 \mathrm{M}$ stock solution $\mathrm{MgSO}_{4}, 2 \mathrm{~g}$ Dextrose, $\mathrm{pH} 6.5$.

PDB/PDA (Potato Dextrose Broth/Agar): Difco ${ }^{\mathrm{TM}}$ PDB and PDA used as indicated in the label.

ICI (1L): $10 \mathrm{~g}$ Dextrose, $0.48 \mathrm{~g} \mathrm{NH} \mathrm{NO}_{3}, 5 \mathrm{~g} \mathrm{KH} \mathrm{PO}_{4}, 1 \mathrm{~g} \mathrm{MgSO}$.7H2O, $1 \mathrm{~mL} 1000 \times$ trace elements.

$1000 \times$ trace elements $(100 \mathrm{~mL}): 2.2 \mathrm{~g} \mathrm{ZnSO}_{4} .7 \mathrm{H}_{2} \mathrm{O}, 1.1 \mathrm{~g} \mathrm{H}_{3} \mathrm{BO}_{3}, 0.5 \mathrm{~g} \mathrm{MnCl}_{2} .4 \mathrm{H}_{2} \mathrm{O}$, $0.5 \mathrm{~g} \mathrm{FeSO}_{4} .7 \mathrm{H}_{2} \mathrm{O}, 0.16 \mathrm{~g} \mathrm{CoCl}_{2} .5 \mathrm{H}_{2} \mathrm{O}, 0.16 \mathrm{~g} \mathrm{CuSO}_{4} .5 \mathrm{H}_{2} \mathrm{O}, 0.11 \mathrm{~g}\left(\mathrm{NH}_{4}\right)_{6} \mathrm{Mo}_{7} \mathrm{O}_{24} .4 \mathrm{H}_{2} \mathrm{O}$, $5 \mathrm{~g} \mathrm{Na}_{4}$ EDTA.

\subsection{Strain Construction and Transformation}

The predicted sequence of the backbone polyketide synthase bik1 ortholog in Fol was identified based on nucleotide and protein BLAST search with bik1 characterized in $F$. fujikuroi (FFUJ_06742) as the template. Sequence alignment identified homologous regions in genes FOXG_04757 and FOXG_04758 (Figure S6A). Both putative genes aligned with bik1 of $F$. fujikuroi indicating they are both part of bik1 of Fol. Thus, the two genes FOXG_04757 and FOXG_04758 have been annotated as bik1 in the rest of the text and Figureures. The WT Fol was used as the parent strain to delete $b i k 1$ with the homologous recombination-based integration of the hygromycin resistance gene $h p h$ at the bik1 locus. $h p h$ was amplified from the plasmid pAN7-1. The schematic representation of the bik1 gene replacement with $h p h$ is shown in Figure S6B. The three amplified fragments ( $5^{\prime}$ flank upstream of bik1, hph from plasmid pAN7-1, $3^{\prime}$ flank downstream of bik1) were fused together to form the deletion cassette with the double-joint PCR described elsewhere.

Transformation of $\mathrm{Fol}$ protoplasts was performed based on the protocol below to generate the deletion strains (denoted as 2.5 and 2.C in Figure 6C). The reagents required for transformation include; $\mathrm{PDB}, \mathrm{KCl} / \mathrm{CaCl}_{2}$ buffer $(1.2 \mathrm{M} \mathrm{KCl}, 50 \mathrm{mM} \mathrm{CaCl}$ ), STC solution (0.8 M sorbitol, $50 \mathrm{mM} \mathrm{CaCl}_{2}, 50 \mathrm{mM}$ Tris-HCl, $\mathrm{pH}$ 7.5), TEC solution (10 mM Tris-HCl, $\mathrm{pH}$ $7.5,1 \mathrm{mM}$ EDTA, $40 \mathrm{mM} \mathrm{CaCl}$ ), PEG solution $(60 \%(\mathrm{w} / \mathrm{v})$ polyethylene glycol MW 4000 in $0.6 \mathrm{M}$ MOPS). The regeneration medium used to plate protoplast-DNA-PEG mixture includes $\mathrm{MgSO}_{4} 7 \mathrm{H}_{2} \mathrm{O}(0.5 \mathrm{~g} / \mathrm{L}), \mathrm{KH}_{2} \mathrm{PO}_{4}(1 \mathrm{~g} / \mathrm{L}), \mathrm{KCl}(0.5 \mathrm{~g} / \mathrm{L}), \mathrm{NaNO}_{3}(2 \mathrm{~g} / \mathrm{L})$, glucose $(20 \mathrm{~g} / \mathrm{L})$, sucrose $(200 \mathrm{~g} / \mathrm{L})$, oxoid agar $(14 \mathrm{~g} / \mathrm{L}$ for regeneration plates and $5 \mathrm{~g} / \mathrm{L}$ for top agar).

Spores $\left(5 \times 10^{8}\right)$ were inoculated in $100 \mathrm{~mL}$ PDB at $28{ }^{\circ} \mathrm{C}, 250 \mathrm{rpm}$ for $12-16 \mathrm{~h}$. Germlings were harvested with centrifugation and washed with $\mathrm{KCl} / \mathrm{CaCl}_{2}$ buffer (concentration mentioned in the previous paragraph) twice before resuspension in the enzyme cocktail (200 mg Lyzing Enzyme (Sigma), 150 mg Driselase (Fluca), 15 mg Lyticase (Sigma), $10 \mathrm{mg}$ Yatalase (Takara) in $50 \mathrm{~mL} \mathrm{KCl} / \mathrm{CaCl}_{2}$ buffer). The mixture was incubated for $2 \mathrm{~h}$ at $28{ }^{\circ} \mathrm{C}$ at $100 \mathrm{rpm}$ and routinely examined for protoplasts. When ready, protoplasts were collected by filtering through a double-layered Miracloth. This was followed by centrifugation and washing with two volumes of STC. The protoplasts were then pelleted with centrifugation and resuspended in STC. Next, 5-10 $\mu$ g of the transforming DNA was mixed with TEC solution to a final volume of $60 \mu \mathrm{L}$. About one hundred microliters of protoplasts was added to TEC solution and incubated on ice for $20 \mathrm{~min}$. One hundred and sixty microliters of PEG was mixed in and incubated at room temperature for $15 \mathrm{~min}$. One 
milliliter of STC was then added. The mixture was centrifuged to pellet protoplasts and resuspended in STC. The protoplasts were spread onto a plate containing the regeneration medium and incubated at $28^{\circ} \mathrm{C}$ overnight. Hygromycin B was then overlaid at $100 \mu \mathrm{g} / \mathrm{mL}$ followed by incubation for 3-5 days.

Transformants were picked as hygromycin-resistant single colonies growing out of hygromycin amended plates containing the protoplasts and the deletion cassette. All transformants were screened by PCR and a single insertion at the bik1 locus was confirmed with a Southern blot using [ $\alpha 32 \mathrm{P}] \mathrm{dCTP}$ (PerkinElmer, USA) to label the DNA probes (schematic in Figure S6B and results in Figure S6C). The primers used for mutant construction and screening are listed in Table S3. Lack of bikaverin production by the deletion mutant was confirmed with metabolite extraction and HPLC analysis (Figure S6D).

\subsection{Tomato Coinfection Procedures}

Conidia of Fol used for infection were collected from 5 to 6-day old liquid cultures as described earlier. Overnight cultures of $R$. solanacearum were grown to OD $>1$ to obtain bacterial cells for infection. Bacterial cells and fungal conidia were washed twice in sterile double distilled water and mixed together in flasks at a ratio of 1:1000 $\left(2.5 \times 10^{5}\right.$ cells of the bacterium and $2.5 \times 10^{8}$ conidia of Fol in $30 \mathrm{~mL}$ ) to obtain the co-inoculum to perform co-infections. Inoculum of either the bacteria alone or the fungal conidia alone was used to perform single infections. 18 to 20-day old tomato plants of the cultivar 'Moneymaker' (from ParkSeed) were uprooted from existing pots, rinsed in running water three times, and then dipped well-mixed in single or co-inocula for $3 \mathrm{~min}$. These plants with dripping roots were then transplanted into healthy unautoclaved soil and monitored for plant disease (Figure S1). The plants were grown under consistent and controlled conditions at $28^{\circ} \mathrm{C}$ and a $12 \mathrm{~h}$ photoperiod. Plants were watered with water or Hoagland's solution alternatively. Disease severity values were assigned to each individual plant based on the percentage of leaves that showed wilting phenotype:1 (1-25\% wilting), 2 (26-50\%), 3 (51-75\%), and $4(76-100 \%)$.

\subsection{Assessment of Bacterial Adhesion}

Four-day-old tomato seedlings germinated on $1 \%$ water agar were laid out on a new water agar plate (Figure S5A). A $2 \mathrm{~cm}$ region of the root was marked and $10 \mu \mathrm{L}$ of coinoculum $\left(10^{4} \mathrm{R}\right.$. solanacearum cells $/ \mathrm{mL}$ and $10^{7} \mathrm{Fol}$ conidia $\left./ \mathrm{mL}\right)$ was applied along the length. The infected plants were incubated for $2 \mathrm{~h}$ at $28^{\circ} \mathrm{C}$. The $2 \mathrm{~cm}$ portion was excised, washed thoroughly with agitation, and pressed in between sheets of filter paper. The root pieces were homogenized and plated on CPG amended with $130 \mu \mathrm{g} / \mathrm{mL}$ cycloheximide to select for bacterial colony growth.

\subsection{Assessment of Microbial Load in Planta}

At 9 days post infection (dpi), $\sim 0.1 \mathrm{~g}$ of stem $1-2 \mathrm{~cm}$ above the cotyledons were excised, homogenized, and dilution-plated on bacterial selective (CPG $+130 \mu \mathrm{g} / \mathrm{mL}$ cycloheximide) or fungal selective (PDA $+100 \mu \mathrm{g} / \mathrm{mL}$ ampicillin) media. Bacterial and fungal colonies were normalized to the corresponding individual tissue weights.

\subsection{Rhizosphere Secretome Growth Analyses}

Six to seven-day-old tomato seedlings germinated on $1 \%$ water agar were used. Thirty seedlings were pooled per technical replicate to account for plant-to-plant variation. The seedlings were placed in $5 \mathrm{~mL}$ of chemotaxis buffer [20] in $50 \mathrm{~mL}$ conical tubes along with single or co-inocula. $R$. solanacearum cells were inoculated to a final concentration of $5 \times 10^{4}$ cells $/ \mathrm{mL}$ and Fol conidia to a final concentration of $5 \times 10^{7}$ conidia $/ \mathrm{mL}$. The setup was incubated for $24 \mathrm{~h}$ after which the buffer along with the secreted metabolites were collected and filtered through a $0.2 \mu \mathrm{m}$ filter. The secretome collected was plated to confirm the lack of microbial cells. $R$. solanacearum growth over time was assessed with growth curves over $42-60 \mathrm{~h}$ as appropriate in $96-$ well plates. The crude extracts and fractionated 
crude extracts were resuspended in an 80:20 acetonitrile-water mixture. This mixture was added to a final concentration of 5\% in Boucher's Minimal Medium and appropriate controls were used. Optical density at $600 \mathrm{~nm}$ was read at $1 \mathrm{~h}$ intervals. The area under each growth curve was calculated as a measure of overall bacterial growth.

\subsection{Metabolite Extraction and Fractionation}

Secondary metabolite extraction from Fol pure cultures was performed as described in Spraker et al. 2018 [28]. Metabolite extraction from the secretomes started with the addition of equal volumes of methanol and hexane to the collected aqueous secretome in a separating funnel. After mixing, the hexane layer separated (top layer) and contained eluted fats and oils. The collected methanol layer (bottom layer) was poured back into the separating funnel. This was topped off with ethyl acetate (ethyl acetate:methanol in a 4:1 ratio). A few drops of water were added until the layers separated. The aqueous layer (bottom layer) and the ethyl acetate layer (top layer) were collected separately. All phases (hexane, methanol, or ethyl acetate) were evaporated under reduced pressure and each crude extract was reconstituted in 80:20 acetonitrile:water at $200 \mathrm{mg} / \mathrm{mL}$ by dry weight of the crude extract. Fractionation of the co-infection crude extract from the ethyl acetate phase was accomplished with a preparatory HPLC (details in the following section) and fractions were collected every $2 \mathrm{~min}$. The fractions were evaporated and reconstituted in an 80:20 acetonitrile:water mixture at $100 \mathrm{mg} / \mathrm{mL}$.

\subsection{Analytical Chemistry}

HPLC-DAD was performed on a Gilson GX-271 Liquid Handler with a system 322 H2 Pump connected to a 171 Gilson Diode Array Detector. The XBridge C18 $3.5 \mu \mathrm{m}$ $4.6 \times 150 \mathrm{~mm}$ column was used for the analytical run with a flow rate of $0.8 \mathrm{~mL} / \mathrm{min}$. HPLC grade water with $0.5 \%$ formic acid (solvent A) and HPLC grade acetonitrile with $0.5 \%$ formic acid (solvent B) were used with the gradient: 0 min, 20\% Solvent B; 2 min, 20\% Solvent B; $15 \mathrm{~min}, 95 \%$ Solvent B; $20 \mathrm{~min}, 95 \%$ Solvent B; $20 \mathrm{~min}, 20 \%$ Solvent B; $25 \mathrm{~min}$, Solvent B. An XBridge BEH C18 OBD Prep Column (130 ̊, $5 \mu \mathrm{m}, 19 \mathrm{~mm} \times 250 \mathrm{~mm})$ with an XBridge BEH C18 Prep Guard Cartridge $(130 \AA, 5 \mu \mathrm{m}, 19 \mathrm{~mm} \times 10 \mathrm{~mm})$ was used for preparative HPLC with a flow rate of $16 \mathrm{~mL} / \mathrm{min}$. HPLC grade water with $0.5 \%$ formic acid (solvent A) and HPLC grade acetonitrile with $0.5 \%$ formic acid (solvent $\mathrm{B}$ ) were used with the following gradient $0 \mathrm{~min}, 20 \%$ Solvent B; $2 \mathrm{~min}, 20 \%$ Solvent B; $15 \mathrm{~min}, 95 \%$ Solvent B; 20 min, 95\% Solvent B; 20 min, 20\% Solvent B; 25 min, Solvent B. Data acquisition and analysis were performed with TRILUTION LC V3.0.

UHPLC-HRMS was performed on a Thermo Scientific-Vanquish UHPLC system connected to a Thermo Scientific Q Exactive Orbitrap mass spectrometer in ES+ and ESmode between $200 \mathrm{~m} / \mathrm{z}$ and $1400 \mathrm{~m} / \mathrm{z}$ to identify metabolites. A Zorbax Eclipse XDB-C18 column $(2.1 \times 150 \mathrm{~mm}, 1.8 \mu \mathrm{m} 123$ particle size $)$ was used with a flow rate of $0.2 \mathrm{~mL} / \mathrm{min}$. LC-MS grade water with $0.5 \%$ formic acid (solvent A) and LCMS grade acetonitrile with $0.5 \%$ formic acid (solvent B) were used with the gradient: $0 \mathrm{~min}, 20 \%$ Solvent B; $2 \mathrm{~min}, 20 \%$ Solvent B; 15 min, 95\% Solvent 126 B; 20 min, 95\% Solvent B; 20 min, 20\% Solvent B; 25 min, Solvent B. Data acquisition and analysis for the UHPLC-MS were performed with Thermo Scientific Xcalibur software Version 3.1.66.10. The acquired data were also analyzed with Compound Discoverer 3.2 to generate plots Figure S10.

\subsection{Evaluation of Extract Efficacy against Bacterial Disease}

To evaluate whether the fractions from co-infection crude extract protected tomato plants from $R$. solanacearum disease, an infection model was developed on Hoagland's medium. 6-day old seedlings germinated on 1\% water agar were transferred to Hoagland's agar and incubated at $28{ }^{\circ} \mathrm{C}$ with a $12 \mathrm{~h}$ photoperiod for 7 days. The plants were then infected by applying $R$. solanacearum suspensions of $5 \times 10^{6}$ cells $/ \mathrm{mL}$ as $1 \mu \mathrm{L}$ droplets at each point covering the root. After the inoculum dried, $1 \%$ of $100 \mathrm{mg} / \mathrm{mL}$ fractionated extracts were applied along the roots, also as $1 \mu \mathrm{L}$ droplets covering the root. One percent 
of an 80:20 acetonitrile:water mixture was used as a solvent control. The plants were incubated at $28^{\circ} \mathrm{C}$ with a $12 \mathrm{~h}$ photoperiod for 6 days before symptoms were recorded.

\subsection{Statistical Analyses}

All statistical analyses were performed with GraphPad Prism version 8.3.0. Normal distribution was tested with Shapiro-Wilk's test. The area under the curve was calculated with the default parameters on GraphPad Prism. Repeated measures ANOVA and post hoc analyses, $\mathrm{t}$-tests, and non-parametric t-tests were performed as appropriate for the experiments and are detailed in the figure legends.

Supplementary Materials: The following are available online at https: / www.mdpi.com/article/ 10.3390/microorganisms9102123/s1, Figure S1: Schematic for co-infection of tomato seedlings, Figure S2: R. solanacearum growth is not inhibited in in vitro co-cultures, Figure S3: Reduction in bacterial wilt during co-infection requires active and specific interactions with $F$. oxysporum $f$. sp. lycopersici, Figure S4: A timeline for F. oxysporum infection, Figure S5: Assessment of R. solanacearum attachment to roots, Figure S6: bik1 knockout construction and validation. (A) Genomic context for bik1 gene in F. oxysporum, Figure S7: Co-culture of R. solanacearum and F. oxysporum in secretome collection buffer does not inhibit bacterial growth, Figure S8: The bioactive molecules in the co-infection secretome do not degrade with heat, Figure S9: R. solanacearum growth in secondary metabolite crude extracts eluted into hexane (A) and methanol (B), Figure S10: Untargeted metabolomic analyses of crude extracts from single and co-infected secretomes, Table S1: $\mathrm{m} / \mathrm{z}$ values for compounds shown in the chromatograms from Figure 4D, Table S2: List of strains used in the study, Table S3: List of primers used in the study.

Author Contributions: N.V. and N.P.K. developed and designed the experiments for the study; N.V., M.J.K., G.N. and P.W. performed the experiments; N.V., C.G. and N.P.K. analyzed and interpreted the data; N.V. and N.P.K. wrote the paper. All authors have reviewed this work. All authors have read and agreed to the published version of the manuscript.

Funding: This work was supported by the National Institute of Food and Agriculture, United States Department of Agriculture, Hatch project 1012878 to N.P.K, the National Institutes of Health under grant 5R01GM112739-06 to N.P.K. and the UW-Madison Food Research Institute's E. Michael and Winona Foster Wisconsin Distinguished Fellowship Award to N.V.

Institutional Review Board Statement: Not Applicable.

Informed Consent Statement: Not Applicable.

Data Availability Statement: All data is available in the main text or the Supplementary Materials. All strains will be provided from the Keller Lab upon request.

Acknowledgments: We thank Antonio Di Pietro, Ernst Oliw and Caitilyn Allen for their generous sharing of microbial strains used in this study. We also thank Corri Hamilton and Mariama Carter for their helpful inputs about the R. solanacearum-tomato pa-thosystem and generous sharing of protocols.

Conflicts of Interest: The authors declare no conflict of interest.

\section{References}

1. Wei, Z.; Gu, Y.; Friman, V.P.; Kowalchuk, G.A.; Xu, Y.; Shen, Q.; Jousset, A. Initial soil microbiome composition and functioning predetermine future plant health. Sci. Adv. 2019, 5, eaaw0759. [CrossRef] [PubMed]

2. Steffan, B.N.; Venkatesh, N.; Keller, N.P. Let's Get Physical: Bacterial-Fungal Interactions and Their Consequences in Agriculture and Health. J. Fungi 2020, 6, 243. [CrossRef]

3. Abdullah, A.S.; Moffat, C.S.; Lopez-Ruiz, F.J.; Gibberd, M.R.; Hamblin, J.; Zerihun, A. Host-Multi-Pathogen Warfare: Pathogen Interactions in Co-infected Plants. Front. Plant Sci. 2017, 8. [CrossRef] [PubMed]

4. Péréfarres, F.; Thébaud, G.; Lefeuvre, P.; Chiroleu, F.; Rimbaud, L.; Hoareau, M.; Reynaud, B.; Lett, J.M. Frequency-dependent assistance as a way out of competitive exclusion between two strains of an emerging virus. Proc. R. Soc. B Biol. Sci. 2014, 281, 20133374. [CrossRef]

5. Susi, H.; Barrès, B.; Vale, P.F.; Laine, A.L. Co-infection alters population dynamics of infectious disease. Nat. Commun. 2015, 6, 1-8. [CrossRef] [PubMed] 
6. Tollenaere, C.; Susi, H.; Laine, A.L. Evolutionary and Epidemiological Implications of Multiple Infection in Plants. Trends Plant Sci. 2016, 21, 80-90. [CrossRef] [PubMed]

7. Krüger, W.; Vielreicher, S.; Kapitan, M.; Jacobsen, I.D.; Niemiec, M.J. Fungal-bacterial interactions in health and disease. Pathogens 2019, 8, 70. [CrossRef] [PubMed]

8. Bakaletz, L.O. Viral-bacterial co-infections in the respiratory tract. Curr. Opin. Microbiol. 2017, 35, 30-35. [CrossRef]

9. Rawson, T.M.; Moore, L.S.P.; Zhu, N.; Ranganathan, N.; Skolimowska, K.; Gilchrist, M.; Satta, G.; Cooke, G.; Holmes, A. Bacterial and Fungal Coinfection in Individuals with Coronavirus: A Rapid Review to Support COVID-19 Antimicrobial Prescribing. Clin. Infect. Dis. 2020, 71, 2459-2468. [CrossRef]

10. Lai, C.C.; Yu, W.L. COVID-19 associated with pulmonary aspergillosis: A literature review. J. Microbiol. Immunol. Infect. 2021, 54, 46-53. [CrossRef]

11. Singh, S.; Gautam, R.K.; Singh, D.R.; Sharma, T.V.R.S.; Sakthivel, K.; Roy, S.D. Genetic approaches for mitigating losses caused by bacterial wilt of tomato in tropical islands. Eur. J. Plant Pathol. 2015, 143, 205-221. [CrossRef]

12. Salanoubat, M.; Genin, S.; Artiguenave, F.; Gouzy, J.; Mangenot, S.; Arlat, M.; Billault, A.; Brottier, P.; Camus, J.C.; Cattolico, L.; et al. Genome sequence of the plant pathogen Ralstonia solanacearum. Nature 2002, 415, 497-502. [CrossRef]

13. Bosland, P.W. Fusarium Oxysporum, a Pathogen of Many Plant Species. Adv. Plant Pathol. 1988, 6, 281-289. [CrossRef]

14. Spraker, J.E.; Wiemann, P.; Baccile, J.A.; Venkatesh, N.; Schumacher, J.; Schroeder, F.C.; Sanchez, L.M.; Keller, N.P. Conserved Responses in a War of Small Molecules between a Plant-Pathogenic Bacterium and Fungi. MBio 2018, 9, e00820-18. [CrossRef]

15. CABI. Ralstonia solanacearum CABI Distribution Data. Available online: https://www.cabi.org/isc/datasheet/45009 (accessed on 1 October 2021).

16. CABI. Fusarium oxysporum f. sp. lycoperisici CABI Distribution Data. Available online: https://www.cabi.org/isc/datasheet/24 660 (accessed on 1 October 2021).

17. Su, L.; Zhang, L.; Nie, D.; Kuramae, E.E.; Shen, B.; Shen, Q. Bacterial tomato pathogen Ralstonia solanacearum invasion modulates rhizosphere compounds and facilitates the cascade effect of fungal pathogen Fusarium solani. Microorganisms 2020, 8, 806. [CrossRef] [PubMed]

18. Leclair, L.W.; Hogan, D.A. Mixed bacterial-fungal infections in the CF respiratory tract. Med. Mycol. 2010, 48, S125-S132. [CrossRef]

19. Yang, S.; Hua, M.; Liu, X.; Du, C.; Pu, L.; Xiang, P.; Wang, L.; Liu, J. Bacterial and fungal co-infections among COVID-19 patients in intensive care unit. Microbes Infect. 2021, 23, 104806. [CrossRef] [PubMed]

20. Yao, J.; Allen, C. Chemotaxis is required for virulence and competitive fitness of the bacterial wilt pathogen Ralstonia solanacearum. J. Bacteriol. 2006, 188, 3697-3708. [CrossRef]

21. Hoffman, M.D.; Zucker, L.I.; Brown, P.J.B.; Kysela, D.T.; Brun, Y.V.; Jacobson, S.C. Timescales and Frequencies of Reversible and Irreversible Adhesion Events of Single Bacterial Cells. Anal. Chem. 2015, 87, 12032-12039. [CrossRef]

22. Mcgarvey, J.A.; Denny, T.P.; Schell, M.A. Spatial-Temporal and Quantitative Analysis of Growth and EPS I Production by Ralstonia solanacearum in Resistant and Susceptible Tomato Cultivars. Phytopathology 1999, 89, 1233-1239. [CrossRef] [PubMed]

23. Caldwell, D.; Kim, B.-S.; Iyer-Pascuzzi, A.S. Ralstonia solanacearum Differentially Colonizes Roots of Resistant and Susceptible Tomato Plants. Phytopathology 2017, 107, 528-536. [CrossRef] [PubMed]

24. Vasse, J.; Frey, P.; Trigalet, A. Microscopic studies of intercellular infection and protoxylem invasion of tomato roots by Pseudomonas solanacearum. Mol. Plant-Microbe Interact. 1995, 8, 241-251. [CrossRef]

25. Lowe-Power, T.M.; Khokhani, D.; Allen, C. How Ralstonia solanacearum Exploits and Thrives in the Flowing Plant Xylem Environment. Trends Microbiol. 2018, 26, 929-942. [CrossRef] [PubMed]

26. Olivain, C.; Humbert, C.; Nahalkova, J.; Fatehi, J.; L’Haridon, F.; Alabouvette, C. Colonization of tomato root by pathogenic and nonpathogenic Fusarium oxysporum strains inoculated together and separately into the soil. Appl. Environ. Microbiol. 2006, 72, 1523-1531. [CrossRef] [PubMed]

27. Lagopodi, A.L.; Ram, A.F.J.; Lamers, G.E.M.; Punt, P.J.; Van den Hondel, C.A.M.J.J.; Lugtenberg, B.J.J.; Bloemberg, G.V. Novel aspects of tomato root colonization and infection by Fusarium oxysporum f. sp. radicis-lycopersici Revealed by confocal laser scanning microscopic analysis using the green fluorescent protein as a marker. Mol. Plant-Microbe Interact. 2002, 15, 172-179. [CrossRef] [PubMed]

28. Wen, T.; Zhao, M.; Liu, T.; Huang, Q.; Yuan, J.; Shen, Q. High abundance of Ralstonia solanacearum changed tomato rhizosphere microbiome and metabolome. BMC Plant Biol. 2020, 20, 166. [CrossRef] [PubMed]

29. Kamilova, F.; Kravchenko, L.V.; Shaposhnikov, A.I.; Makarova, N.; Lugtenberg, B. Effects of the tomato pathogen Fusarium oxysporum f. sp. radicis-lycopersici and of the biocontrol bacterium Pseudomonas fluorescens WCS365 on the composition of organic acids and sugars in tomato root exudate. Mol. Plant-Microbe Interact. 2006, 19, 1121-1126. [CrossRef]

30. Bais, H.P.; Weir, T.L.; Perry, L.G.; Gilroy, S.; Vivanco, J.M. The role of root exudates in rhizosphere interactions with plants and other organisms. Annu. Rev. Plant Biol. 2006, 57, 233-266. [CrossRef]

31. Bhattarai, B. Variation of Soil Microbial Population in Different Soil Horizons. J. Microbiol. Exp. 2015, 2, 00044. [CrossRef]

32. Cai, P.; Sun, X.; Wu, Y.; Gao, C.; Mortimer, M.; Holden, P.A.; Redmile-Gordon, M.; Huang, Q. Soil biofilms: Microbial interactions, challenges, and advanced techniques for ex-situ characterization. Soil Ecol. Lett. 2019. [CrossRef]

33. Sharma, K.; Palatinszky, M.; Nikolov, G.; Berry, D.; Shank, E.A. Transparent soil microcosms for live-cell imaging and nondestructive stable isotope probing of soil microorganisms. eLife 2020, 9, e56275. [CrossRef] 
34. Abeysinghe, G.; Kuchira, M.; Kudo, G.; Masuo, S.; Ninomiya, A.; Takahashi, K.; Utad, A.S.; Hagiwara, D.; Nomura, N.; Takaya, N.; et al. Fungal mycelia and bacterial thiamine establish a mutualistic growth mechanism. Life Sci. Alliance 2020, 3. [CrossRef]

35. Peleg, A.Y.; Hogan, D.A.; Mylonakis, E. Medically important bacterialg-fungal interactions. Nat. Rev. Microbiol. 2010, 8, 340-349. [CrossRef] [PubMed]

36. Spraker, J.E.; Sanchez, L.M.; Lowe, T.M.; Dorrestein, P.C.; Keller, N.P. Ralstonia solanacearum lipopeptide induces chlamydospore development in fungi and facilitates bacterial entry into fungal tissues. ISME J. 2016, 10, 2317-2330. [CrossRef] [PubMed]

37. Höfer, A.M.; Harting, R.; Aßmann, N.F.; Gerke, J.; Schmitt, K.; Starke, J.; Bayram, Ö.; Tran, V.T.; Valerius, O.; Braus-Stromeyer, S.A.; et al. The velvet protein Vel1 controls initial plant root colonization and conidia formation for xylem distribution in Verticillium wilt. PLoS Genet. 2021, 17, e1009434. [CrossRef] [PubMed]

38. de Lamo, F.J.; Spijkers, S.B.; Takken, F.L.W. Protection to tomato wilt disease conferred by the nonpathogen Fusarium oxysporum Fo47 is more effective than that conferred by avirulent strains. Phytopathology 2021, 111, 253-257. [CrossRef] [PubMed]

39. Graham, J. Survival of Pseudomonas solanacearum Race 3 in Plant Debris and in Latently Infected Potato Tubers. Phytopathology 1979, 69, 1100. [CrossRef]

40. Bacterial Wilt-Ralstonia solanacearum. Available online: https://extension.psu.edu/bacterial-wilt-ralstonia-solanacearum (accessed on 6 June 2021).

41. Netzker, T.; Flak, M.; Krespach, M.K.; Stroe, M.C.; Weber, J.; Schroeckh, V.; Brakhage, A.A. Microbial interactions trigger the production of antibiotics. Curr. Opin. Microbiol. 2018, 45, 117-123. [CrossRef] 